Fecha de recepción: diciembre 2018 Fecha de aceptación: marzo 2019 Versión final: abril 2019

\section{El diseño textil como resultado de la interacción étnica en Quito, a finales del siglo XVIII}

Annabella Ponce Pérez ${ }^{\star}$ y Carolina Cornejo Ramón ${ }^{\star *}$

Resumen: Este artículo tiene como finalidad realizar una aproximación a los textiles: su diseño e interpretación, a través de la escultura San Lucas Arcángel, restaurado en el taller de Bernardo de Legarda, realizado en Quito en la segunda mitad del siglo XVIII. El mismo que da cuenta del aspecto artesanal cuanto de la incorporación de elementos locales en el diseño textil de su indumentaria. El estudio visibiliza la materialización del mestizaje cultural, resultado de las diversas relaciones entre las capas sociales de la sociedad quiteña en la etapa colonial. El diseño textil de dicha obra, evidencia el proceso artesanal de elaboración cuanto el mestizaje que trasciende las fronteras étnicas y sociales del siglo XVIII. El aporte de la presente investigación tiene como fin contribuir a la memoria histórica de los textiles e indumentaria, que forman parte del patrimonio cultural, los mismos que no han sido conservados ni protegidos por las políticas y gestión de salvamento de los bienes patrimoniales, por parte del gobierno local. Si bien la declaración de Quito, como Patrimonio Cultural de la Humanidad, por parte de la UNESCO, ha permitido salvaguardar los bienes culturales, tanto la indumentaria como los textiles no han sido considerados en este proceso.

Palabras clave: Diseño textil - Barroco - Imaginería - Mestizaje cultural - Procesos artesanales

[Resúmenes en inglés y portugués en la página 191]

(*) Diseñadora de Modas y Textiles de la Fundación Universitaria del Área Andina (Bogotá), Especialista en Relaciones Internacionales de la Universidad Jorge Tadeo Lozano (Bogotá) y Máster en Diseño de la Universidad de Palermo (Buenos Aires). Actualmente cursa el Doctorado en Diseño de la Universidad de Palermo y se desempeña como docente e investigadora en la Facultad de Comunicación, Artes y Humanidades de la Universidad UTE (Quito), pertenece al grupo de investigación: Diálogo Visual, Intercultural y Productivo.

${ }^{(*)}$ Comunicadora de la Universidad San Francisco de Quito y Máster en Dirección de Comunicación de la Universidad de las Américas (Quito), se desempeña como docente e investigadora en la Facultad de Comunicación, Artes y Humanidades de la Universidad UTE (Quito), pertenece al grupo de investigación: Comunicación, Medios, Publicidad y Cultura Digital. 


\section{Introducción}

El siglo XVIII es una época de importantes cambios de índole económica, política y social para Quito desde el inicio del periodo. Se destaca sobre todo la crisis de los textiles, la cual provocó una profunda reconfiguración de la estructura social y productiva, debido al cierre de los talleres textiles rurales de producción artesanal (obrajes), y a la migración de los indígenas obrajeros a la ciudad.

Cabe resaltar que los textiles de elaboración artesanal, a lo largo del periodo de colonización tuvieron un rol determinante en el desarrollo económico de la Real Audiencia de Quito. La producción textil estuvo organizada en centros de carácter artesanal y preindustrial denominados obrajes, en ellos se realizaban todas las labores relacionadas con la producción de tejidos artesanales, desde la obtención de la fibra, el proceso de hilado, tinturado y la construcción de las telas. La producción abastecía las demandas del polo minero alto peruano de Potosí y centro administrativo limeño. (Espinoza y Achig 1980, p. 34). En el siglo XVII, éstos aportaron a la bonanza económica de la ciudad. Sin embargo las Reformas Borbónicas ${ }^{1}$ impactaron la red comercial y productiva de los textiles quiteños de producción artesanal. Impusieron una nueva dinámica que incidió directamente en la producción local artesanal de los tejidos de tierra y afianzó una crisis económica a lo largo del siglo XVIII. Por otra parte, la producción artística alcanzó gran prestigio debido a la técnica y la variedad de obras pictóricas y escultóricas, se puede mencionar a artistas como Bernardo de Legarda, Manuel Chilli, entre otros, quienes obtuvieron reconocimiento a lo largo del territorio americano, así como en España. "Es conocido que durante el siglo anterior la ciudad de Quito se había consolidado como un centro de capacitación y producción artístico-artesanal que le permitió ser tempranamente autosuficiente" (Kennedy, 2002, p73). A través de este estudio se pretende identificar los elementos morfológicos locales que aportan en el diseño textil artesanal de la época presente en la imaginería quiteña. Para la consecución de dicho objetivo se seleccionó la obra denominada San Lucas Evangelista, elaborada en 1654, con la técnica de estofado y esgrafiado, por el sacerdote Franciscano Padre Carlos, la cual fue restaurada por el artista quiteño Bernardo de Legarda en 1762. La selección de esta obra se debe a las características y técnicas de simulación del textil. Pese a que la misma se realizó aproximadamente cien años antes de su restauración, es evidente la transferencia de elementos culturales que se plasman en la simulación del textil. Cabe anotar que la indumentaria es una fuente de información, que permiten inferir diversos aspectos de la época. Sin embargo, debido al carácter polisémico de la misma se requiere contrastar con fuentes históricas, con el fin de identificar aspectos que permitan inferir los cambios y continuidades en el ámbito social, así como la intervención de los actores en su realización. El rol de la indumentaria dentro de las sociedades tributa a la construcción de un relato histórico. Lo que se pretende estudiar corresponde esencialmente a la representación del textil artesanal a través de la indumentaria, es decir a través de la imagen, sin que en este análisis sea relevante la herramienta de representación.

En la realización de la escultura quiteña del siglo XVIII se encuentran dos tipos de ropaje, uno como parte de la talla o complemento en las que es posible vestir las esculturas y por tanto, quedan subordinadas a la estructura corporal. El segundo tipo como parte de la talla, en la cual los artistas exponen su técnica para el diseño y construcción de la indumentaria. 
La obra seleccionada corresponde a la imaginería quiteña del siglo XVIII. Gran parte de la producción artística estuvo influenciada por las presiones religiosas de la época, en este caso la escultura de San Lucas Evangelista, patrono de los médicos y pintores de la orden Franciscana. La indumentaria de la misma da cuenta de la relación que se manifiesta entre el cuerpo y el vestido, debido a que el indumento altera la noción de espacio, y constituye un elemento afianzador del mensaje.

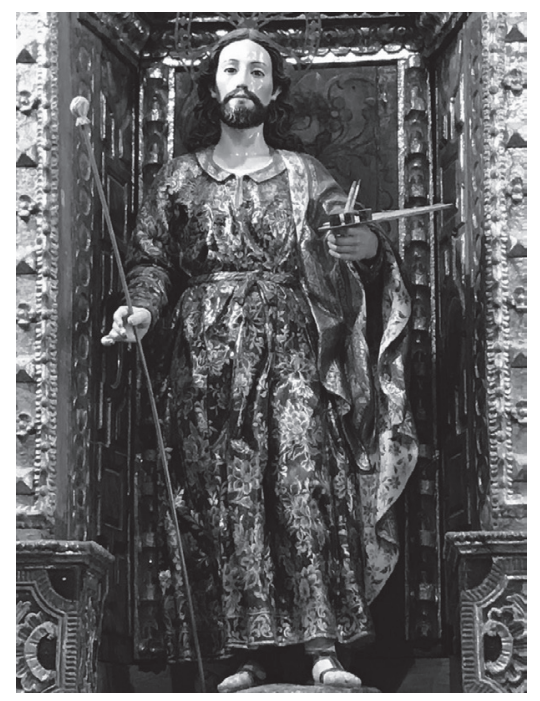

Figura 1. San Lucas Evangelista.

Recuperado de: https://theworldnews.net/ ec-news/obra-de-bernardo-de-legarda-seencontro-en-la-capilla-de-cantuna

La ornamentación del vestido y la simulación de los bordados en oro y plata a partir de la técnica del estofado, contribuyen a exaltar la obra. San Lucas fue ataviado simulando la textura del brocado, la cual tributa a la fuerza expresiva de la imagen.

Dicha obra se realizó en el periodo barroco, en este caso la vestimenta alcanza a anular completamente la silueta corporal y con ello logra incluir como un solo cuerpo, el vestido tallado y la sobre posición de prendas trasciende los límites de lo público y lo privado. Asimismo en ocasiones juega con las caras interiores y exteriores de las capas textiles. Los textiles que se insinúan en la obra ejercitan la movilidad, resbalan, vuelan, dan un aspecto de continuo movimiento, enfatizando el pliegue, el que continúa incesante su trayecto.

Además, el diseño del textil es abundante, con movimientos ondulantes los que decantan en el repliegue, acompañados de una paleta de color en oro, plata y carmesí, los finos acabados de encaje y cenefas sobre las prendas evocan como símbolo de distinción social. "Las figuras no se representan quietas o en postura de reposo, sino siempre sugiriendo un constante momento de equilibrio inestable, equilibrio que se verifica en el proceso de culminación de movimiento que nunca termina” (Pantoja, 2008, p.128). 
En el barroco se marca, en la escultura, una dualidad entre la percepción del movimiento y el reposo, la luz y penumbra, luminosidad y tiniebla, caracterizan el dramatismo que emerge acompañado del drapeado y voluptuosidad de las prendas, la paleta cromática en la talla y la policromía materializan los diversos estados del alma.

En torno a los textiles se generan diferentes tipos de relaciones, comerciales, sociales, culturales. Estas relaciones se filtran en las capas sociales y grupos étnicos, los que finalmente se convocan en torno a la producción artesanal, construcción y uso de la indumentaria.

\section{Relaciones comerciales de los textiles}

Las condiciones económicas a lo largo del silgo XVIII intervinieron el concepto estético de la época, las características y simbología de los textiles se convirtieron en un indicador de posición social, símbolos de poder y distinción (Bourdieu, 1979). En efecto esto avíos proyectaban en las personas que lo portaban ciertos privilegios en la sociedad y la política. Por ello, los españoles, mestizos acomodados y los miembros de la Iglesia adquirieron telas importadas para construir sus trajes de manera artesanal. En tanto, que la población empobrecida por la crisis se limitaba a confeccionar sus trajes con los textiles de tierra.

El ideal de posición social y poder, envidiado por los nativos, debido a la cantidad de textiles importados, incidió para que el pueblo ambicionara las modas extranjeras y tratara de imitarlas a partir del uso o simulación de estos trajes extranjeros.

Las relaciones comerciales en Quito, referentes al mercado de los textiles y el uso de la vestimenta, estaban directamente relacionadas con las categorías étnicas y funcionaban como símbolo de diferenciación social.

Las formas de producción artesanal de los textiles, los intereses comerciales, el diferencial de costos económicos permiten entender el modo en el que en una prenda se inscriben a partir de la materia prima, el modo de producción, las formas y los usos diferentes pertenencias sociales y relaciones de poder.

Para identificar la importancia de los textiles y de su producción artesanal en Quito y las dinámicas sociales que se tejieron en torno a ellas, se contrastaron las fuentes escritas con el fin identificar los patrones de producción artesanal y circulación. Esto debido a que los textiles estaban sujetos a los controles sociales y a la redefinición de las políticas. (Appadurai, 1991, p. 22)

Los textiles tejidos de manera artesanal en Quito, no fueron los únicos que se consolidaron en la Real Audiencia, otras ciudades de la región a través de los tejidos también contribuyeron al crecimiento económico de las colonias; sin embargo, las políticas proteccionistas ibéricas impidieron el desarrollo de los centros de producción.

Había gran variedad de textiles que circulaban desde Nueva España hasta el sur del continente, denominados textiles de mar, que ingresaban por los puertos de Callao, Guayaquil o Panamá, generalmente provenían de Manila y eran originarios de Europa, Asia e India. Por su parte, los textiles de tierra que se fabricaban localmente. 


\section{Los textiles del mar}

Es relevante establecer que los textiles que se comercializaron a lo largo de todas las colonias, tenían diversos orígenes, aquellos que llegaban por el Pacífico a los Puertos desde Nueva España hasta Lima se consideraban textiles llegados del mar, específicamente procedían de Manila, con quien los virreinatos de Nueva España y Lima establecieron una ruta de comercialización desde la etapa temprana de colonización.

España, por ordenanza real, se había constituido el principal proveedor de materia prima a las colonias. Sin embargo, el comercio que se generó a lo largo del pacífico, tuvo una influencia importante para la vida de los habitantes, a nivel económico y social, por lo cual se convirtió en una fuerte influencia cultural.

A pesar de las leyes que prohibían ${ }^{2}$ categóricamente la comercialización con Manila y la redistribución de mercancías desde los puertos de las colonias, el Galeón de Manila afianzó el contrabando a lo largo de las colonias en América desde el siglo XV hasta la etapa de independencia.

Las negociaciones que se realizaron con el Galeón de Manila provocaron una escasez de circulante en el territorio y el detrimento del sector textil quiteño. Entre los bienes extranjeros que se asociación a los chinos priman las telas de diferente calidad y origen: los bramantes, bretañas, estopillas, cambray, sedas, ruan, alemanisco y bayeta fabricados en Castilla, Inglaterra, Segovia, Granada, Flandes, Nápoles, Génova, Alemania y algunos de Rusia o Prusia” (Bonialian, 2014, p.130)

El comercio transpacífico ha sido tratado en diversos análisis historiográficos (Chaunuu 1962, Bernabeu, 1992, Bonialian, 2014) quienes han considerado que los bienes que llegaban a través del galeón de Manila tenían como destino a la población de élite, quienes accedían con facilidad a las finas telas, mientras que los obrajes que habían abastecido el consumo interno, paulatinamente se cerraban. Con el tiempo, todas las clases sociales, fueron vestidas con telas del extremo oriente: los algodones de luzón o la India, sedas de chinas, entre otras.

El orden colonial no dejaba espacio para pretensiones igualitarias; los señores debían identificarse inequívocamente como tales y los indios y gente de color tendrían que mostrar, sin ambigüedades, su condición de vasallos sumisos. De ahí que el lujo, la ostentación y la opulencia fueran una necesidad social y no simple vanidad ocasional de individuos aislados. (Aizpuru, 1996, p.50)

La única vía para la entrada de mercancías asiáticas al Virreinato del Perú fue a través de Acapulco, por medio del transbordo del Galeón de Manila a los conocidos barcos limeños. Desde 1621 se ordenó suspender los viajes de la etapa final de los barcos que navegaban entre Callao, Guayaquil, Panamá, y los puertos de Nicaragua, los cuales procedían de Acapulco, y tenían como fin adquirir bienes de Manila. (Bonalian, 2017) 
Las más serias revelaciones de las condiciones en el Perú, fueron hechas por la comisión real de misioneros, entre ellos Jorge Juan y Antonio de Ulloa, quienes visitaron las colonias en 1735, acompañando la misión Geodésica. A través de sus reportes se pudo comprobar la existencia de productos chinos que ingresaban por el puerto de Guayaquil, y posteriormente se comercializaba en Quito. Ellos mencionan que: "predominaban las telas orientales en el atuendo de la población española, las vestiduras de los sacerdotes y los mantos y las medias de seda de limeñas" (Ruiz Gutiérrez, 2005, p. 254)

A pesar de los reales decretos y leyes, en toda la región del Perú, incluida la Audiencia de Quito la importación de mercancías orientales se convirtió en un tráfico frecuente y habitual, que contribuyó con el imaginario de la sociedad quiteña, sobre los aspectos que permitían mejorar su apariencia. Además, para elevar su estatus social y étnico, se procuraba imitar los vestidos de la gente de España.

Las alteraciones estéticas en la apariencia de los pobladores, es un indicador de los cambios que se efectuaban en las esfera política, En este sentido el vestido se convirtió en un elemento evidente del cambio cultural. A su vez, los patrones de consumo de la población y su necesidad por alcanzar un mejor estatus social, devino en la penuria de la industria textil. Más aún, las ordenanzas de Libre Comercio de 1795, fomentaron la importación de textiles en desmedro de la economía de Quito, en tanto Guayaquil como puerto y circulación de mercaderías, adquirió un dinamismo económico, que permitió solventar la crisis en la última década del siglo XVIII.

"La destrucción del tejido indígena y la afluencia de telas foráneas se volvieron símbolos visibles y materiales para los nacionalistas, comparables a aquéllos representados en otras sociedades por motivos literarios o legendarios: la pérdida del país" (Appadurai, 1986, p353). Debido a la cantidad de textiles foráneos que llegaban a Quito, la producción manufacturera artesanal de tejidos, fue perdiendo espacios de comercialización, efectivamente los nuevos textiles llevaron a la destrucción de la producción textilera, la misma que arrastró a toda la economía local.

\section{Los tejidos de castilla}

Los productos que se comercializaban legalmente en las colonias, provenían de los objetos de tierra, los que se producían en ellas. Por otro lado, también se comercializaban los que llegaban a los puertos Caribeños de Nueva Granda y posteriormente se redistribuían en todas las ciudades.

Las ropas de castilla se vendían en todas las colonias, en tiendas en las que también se comercializaban ropa de tierra. Por diferentes vías venían los géneros y efectos de Europa, especialmente los tan apetecidos textiles finos (cáñamo, gante, coleta, listón, crea, brocados, entre otros). (Borchard, 1998, Moreno 2013).

Ya en el siglo XVIII el gran fomento impulsado por parte de los Borbones a las artes suntuarias españolas estimula la creación de nuevas manufacturas textiles, o bien van a apoyar e invertir en fábricas ya existentes, paralizadas e 
improductivas. El País Valenciano de gran tradición en la manufactura textil, y experimentando una cierta resistencia a la crisis, adquiere un nuevo impulso, renueva sus telares y pone en línea de producción una serie de piezas de gran innovación (Dos Santos, 2009, p.54)

\section{Los tejidos de tierra}

Los tejidos de tierra eran elaborados por los indígenas de manera artesanal en los pocos obrajes que se conservaban debido a la crisis. De alguna forma la condición social y de pobreza de los tejedores indígenas, fueron traslados a sus mercancías, por lo tanto, se mostraba poco interés por sus tejidos, como si el espíritu de su condición plebeya e impura la trasladara a la producción de sus textiles. (Appadurai, 1991)

Los nativos tenían gran habilidad en este oficio, debido a que previo a la llegada de los españoles, el conocimiento estaba difundido entre todos los miembros de la comunidad y había sido transmitido de generación en generación. El trabajo en los obrajes les permitió perfeccionar la técnica artesanal y lograr buenos acabados. Éstos son descritos por los viajeros en el siglo XVIII como lo que sigue: "En el territorio de Quito hay, además, muchísimos obrajes y de extraordinario valor para fabricar, paños finos, gruesos y de todo color" (Juan y Ulloa, citado en Romero 2000, p. 35)

Los indígenas asumieron las actividades artesanales relacionadas al tejido, inclusive después del cierre de los obrajes, se dedicaron a esta actividad en el área urbana de forma independiente. Alrededor de los tejidos de tierra se enmarcan una serie de circunstancias interpretativas que tienen un trasfondo social vinculado a condiciones étnicas. Estos tejidos, producto de la labor artesanal de las manos indígenas fueron fácilmente desplazados por aquellos que llegaban de otros lugares. "En general, la ropa de la tierra sería una mercancía asequible para la gente pobre, situación que cambiaría en el siglo XVIII ante la llegada masiva de telas europeas" (Grandez, 2015, p 45)

Los textiles tuvieron un rol importante en la economía de la ciudad, debido a la desmonetización ${ }^{3}$. Por ello se convirtieron en un medio de pago, para cubrir los costos de fabricación de los textiles artesanales indígenas, los que se pagaban en bienes de diverso orden y con mano de obra. Esto amplió su uso como medio de cambio y medida de valor. Los textiles artesanales se convirtieron, así, en una mercadería para intercambiar por alimentos.

La escasa circulación del metálico del período colonial tardío en Quito y en la región, se reflejaba claramente en la organización de los negocios comerciales rara vez los textiles se vendían contra pagos en efectivo inmediatos. La cancelación de las facturas de las ropas de castilla adquiridas en Cartagena o con menor frecuencia en Lima, se contrataba casi siempre en formas de entrega de ropa de la tierra convenidas para varios meses o hasta años” (Büschges, 2007, p. 238) 


\section{Diseño textil quiteño}

El valor que se les concedió a los textiles, no fue propiedad en sí de los objetos, sino un juicio acerca de ellos. "Así, las telas de diferentes texturas, colores o procedencias no sólo comunicaban información a la sociedad, sino que también modificaban la esencia moral y física del individuo" (Appadurai, 1986, p.354)

El impulso textil originado en España, provocó indirectamente el consumo de bienes suntuarios en las colonias e inspiró un cambio en la estética quiteña. También fomentó la representación de los textiles de la indumentaria en la producción artística y trasladó la esa misma representación del estatus social a las imágenes religiosas. La utilización mágica y transformadora podía ser percibida como algo realmente modificado por las cualidades de la vestimenta. Ese espíritu que transita desde la simbología incide también en el estatus de los artesanos, quienes se encargaban de vestir dichas representaciones.

En los relatos de viajeros, Antonio de Ulloa y Jorge Juan, describen el destino de los textiles de castilla para la ornamentación de las casas de los españoles en Quito, manifiestan el uso de telas finas como el damasco carmesí con galeones y granjas de oro, el recubrimiento de terciopelo en las paredes y las habitaciones de sus casas que son visitadas con frecuencia. (citado en Romero, 2000)

Es evidente que el culto por lo suntuario, evocado por las élites de Quito, transfirió esos deseos al sistema de producción, los tejedores artesanos debían satisfacer las necesidades de la población local y particularmente de las élites. Más aún, cuando los tejidos finos comenzaron a escasear debido a la incorporación de España en la guerra de independencia americana, la prohibición de comercializar con otras nacionales y el impedimento de llegar a costas virreinales. Lo antedicho obligó a mejorar la producción interna, por lo tanto a finales del siglo XVIII se tejían artesanalmente galones de oro y plata de diferentes calidades en la ciudad (Larrea, 1802)

El acceso a los textiles extranjeros estaba limitado para la población subalterna (negros, indígenas y mestizos), por cuestiones étnicas, económicas y básicamente por el impedimento social. Sin embargo, esto no obstaculizó que los brocados, sedas y terciopelos pudieran ser resignificados a través de la producción artística.

Cabe anotar que, en el siglo XVIII, las artes se ejecutaba al interior de talleres, en ellos se desarrollaban diversas actividades en torno a la realización objetual. Para ello contaban con aprendices para realizar diversos oficios artesanales, entre ellas, los vestidos de la imaginería. Por lo tanto, la interacción étnica permitió impulsar la actividad textil artesanal y artística de la época. A lo largo de la cadena textil se puede verificar la participación de los actores sociales, quienes contribuyeron con la materialización de la obra.

El taller del mismo Bernardo de Legarda se dedicaba a un sin número de tareas; ejecución de retablos, esculturas o tallas en todo el proceso, pintura sobre lienzo, vidrio y cobre, hechura de marcos de madera y espejos, confección de espejuelos sueltos para incorporar a su obra o vender al menudeo, arreglo de armas, diseño, elaboración parcial o total de retablos y mamparas, elaboración de taller de plata, oro o vestidos para sus esculturas entre otros." (Kennedy, A, 1994, p.68). 
Para identificar los elementos que tributan al diseño textil de Quito, y el aporte étnico y artesanal de los diversos actores sociales intervinientes, el presente estudio utiliza un análisis iconográfico, en tres niveles: pre iconográfico, iconográfico e iconológico, lo cual permite contrastar las fuentes históricas con las fichas de observación de este estudio.

San Lucas Evangelista, pertenece a la imaginería restaurada en 1762 por Bernardo Legarda, su indumentaria está representada por una túnica que llega hasta el tobillo, en el borde inferior se presenta una cenefa que simula el acabado final de la prenda.

La túnica se sujeta con cordón de colores verde, vino y oro. Las mangas de corte recto con puño acompañan el diseño textil de carácter floral, en colores verde y oro. En la composición textil se visibiliza una estructura gráfica que evoca aspectos fitomorfos. A la túnica le acompaña una capa, accesorio que se solía utilizar como parte de la indumentaria masculina en el siglo XVI, además, como se representa en la obra esta se podía llevar terciada sobre uno de los hombros.

La capa con doble cara textil presenta en su superficie externa una cenefa gruesa color oro y rojo compuesta por un diseño geométrico y floral que se repite en módulos dentro de una composición romboidal. En la parte superior de esta cenefa existe otra más delgada, en la cual se invierten los colores predominando el color oro.

La superficie interna de la capa cuenta con un diseño floral con colores blanco, rojo, verde y amarillo ocre. Las flores, de similar tamaño, están compuestas por siete pétalos con perfil dentado, acompañadas de hojas en dos tonalidades de verde, las mismas que componen un módulo que se repite en todo el textil. Esta prenda sobrepuesta a la túnica es similar al ferreruelo de una sola pieza.

El aporte de la población indígena en la realización de la escultura se comprueba a partir de un análisis morfológico de los elementos incorporados en la indumentaria de la obra San Lucas Evangelista. Se realiza un proceso de síntesis de la forma de las piezas que componen la indumentaria, túnica y capa.

Se identifican siete fitoformas, sobre ellas se indaga su origen a través de los manuales de ornamentación de los grabados que se produjeron en España, especialmente en Flandes y España, lugares de donde se reproducen las imágenes que se reprodujeron a lo largo de las colonias durante el siglo XVI, XVII y XVIII. Se identifican tres formas que no corresponden a las formas de los grabados europeos, éstas son comparadas con estudios botánicos de plantas nativas del Ecuador.

En la Ficha de análisis iconográfico Nro 1, se puede observar la forma incorporada en el textil de la túnica, junto a ella la síntesis de la misma. La forma contiene cinco pétalos que nacen de una campana denominada corola tubular. Su morfología presenta características similares a la especie Tetocoma Stands, que es nativa de América, crece desde Estados Unidos hasta Perú, planta endémica de Ecuador, a una altura de 300 a 3000 metros sobre el nivel del mar. (Quintana, 2010). En la paleta de color predomina el tono café, acompaña el gris, sin dejar de resaltar el oro en los bordes de la forma. 


\section{Ficha de análisis iconográfico No. 1}
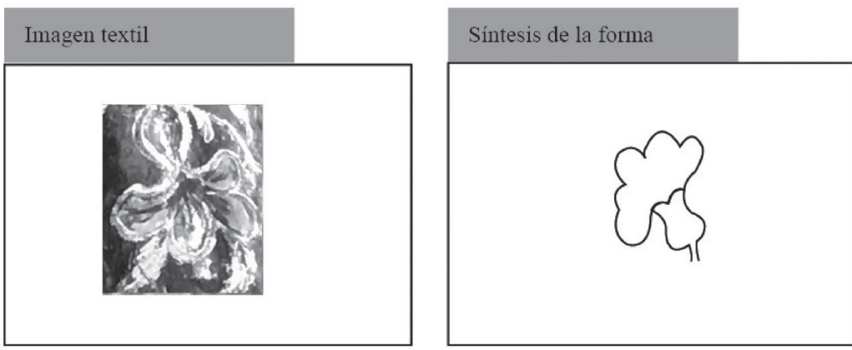

\section{Referencia}

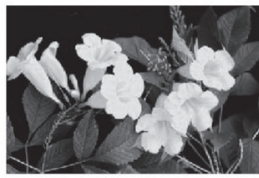

Imagen No. 2: Tecoma Stans Fuente: Kuxtal, 2013

Figura 2. Ficha iconográfica 1. Fuente: Elaboración propia

En la Ficha de análisis iconográfico Nro 2, se observa la forma de la imagen sustraída del textil, la misma que representa una flor con hojas redondas y traslapadas. La curvatura de las cinco hojas se asemeja a la especie hipericum laricifolium juss, la cual crece en América del Sur, en las regiones de Venezuela, Colombia, Ecuador, Perú y Bolivia. Además, se emplea para teñir ropa en diferentes colores. "El tallo y la flor contienen colorantes tales como la hipericina y quercetina" (Fundación botánica de los andes, pr. 4). La paleta de color de esta pieza está formada por una cuatricomía de tonos cafés con pigmentación verde y gris.

\section{Ficha de análisis iconográfico No. 2}
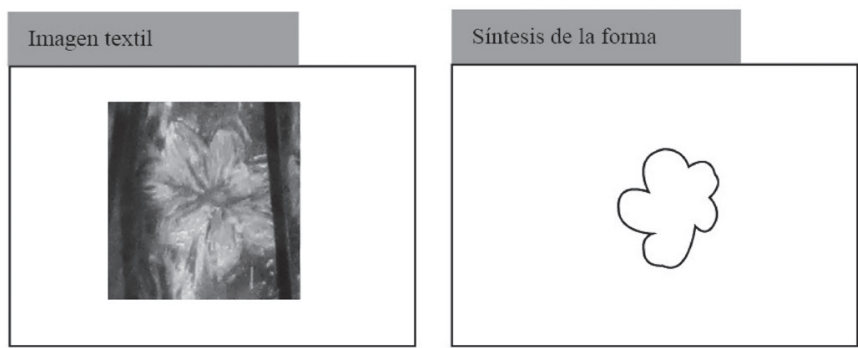

Referencia

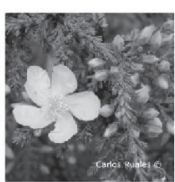

Imagen No. 3. Hypericum laricifolium Juss Fuente: Fundación nativa de los Andes, S/A

Figura 3. Ficha iconográfica 2. Fuente: Elaboración propia.

En la Ficha de análisis icnonográfico Nro 3 se observa el tejido que ciñe la cintura de San Lucas, el mismo que está trenzado en tres tonalidades verde, gris y rojo carmesí, los cuales son aplicados en la escultura de la época. Su tejido coincide con los astrágalos. "Los astrágalos, también conocidos como cordones se disponen en forma de correa y otras molduras como cornisas" (Meyer, 1929, p 196). 


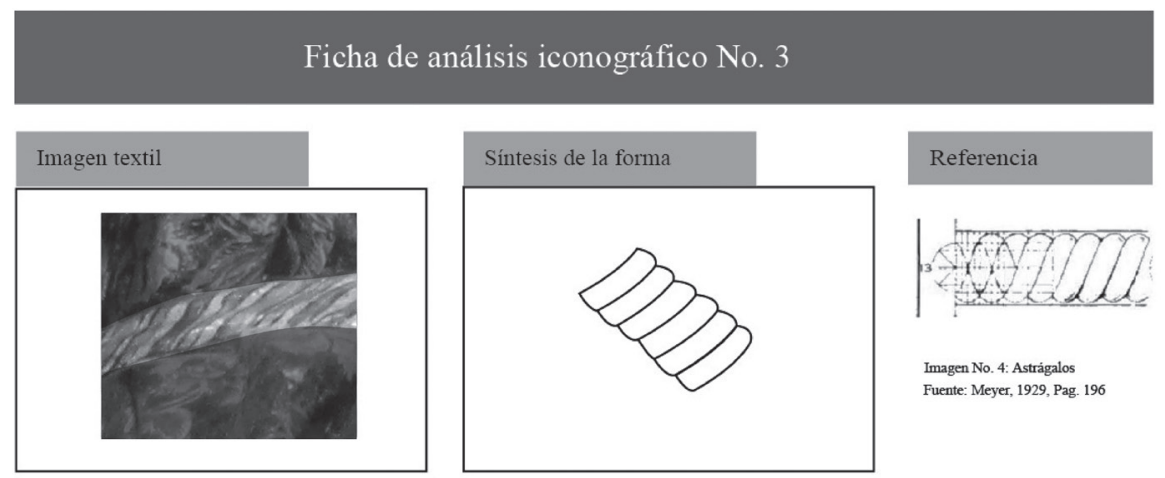

Figura 4. Ficha iconográfica 3. Fuente: elaboración propia.

En la Ficha de análisis icnonográfico Nro 4 se observa un conjunto de pétalos que forman la estructura de la flor. Al igual que la especie nativa Echeverría quitensis (kunt) Lindl, su forma refiere a un arbusto perqueño. "Esta especie se encuentra ampliamente distribuida en América, desde las islas de Caribe hasta Colombia, Ecuador, Brasil, y Bolivia”. (Fundación Botánica de los Andes, pr. 1). La paleta de color está compuesta por rojos con distinta saturación, el oro predomina en los filos de la forma.

\section{Ficha de análisis iconográfico No. 4}
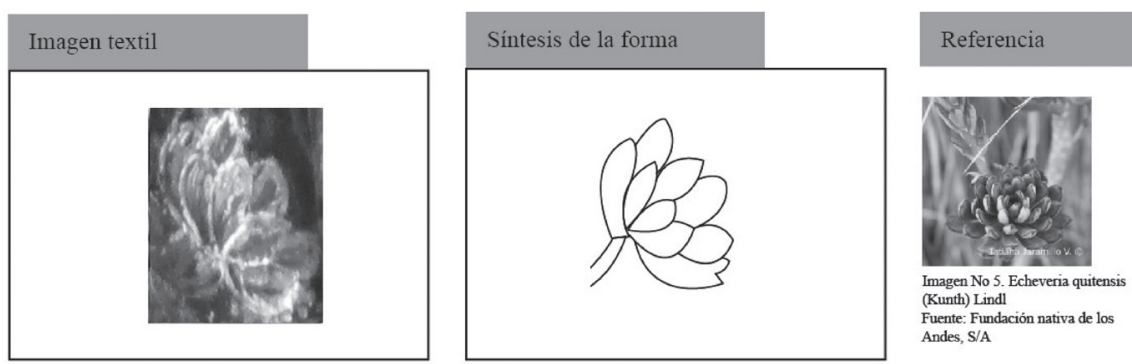

Figura 5. Ficha iconográfica 4. Fuente: elaboración propia

En la Ficha de análisis icnonográfico Nro 5 se observa la hoja de acanto descrita en el Manual de ornamentación. La misma, presenta líneas internas que reflejan luz y sombra, el perfil dentado se repite en varias aplicaciones a lo largo del textil. "La concepción y reproducción del borde de la hoja, es lo verdaderamente característico en los distintos 
periodos del estilo" (Meyer, 1929, p51). La paleta de color de la hoja de acanto está compuesta por una cuatricomía de colores cafés con tonalidad verde, predominando en esta forma el oro y el amarillo.

\section{Ficha de análisis iconográfico No. 5}
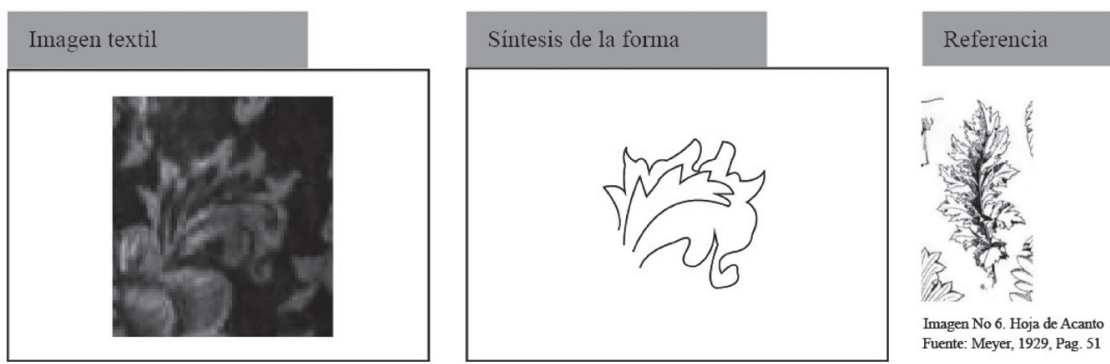

Figura 6. Ficha iconográfica 5. Fuente: elaboración propia

En la Ficha de análisis icnonográfico Nro 6 se representa la cenefa inferior de la túnica, realizada en una composición floral, corresponde a la cinta de follaje y zarcillos de Meyer, la composición contiene hojas dispuestas en ramas curvilíneas. (Meyer, 1929, p 190). La paleta de color está formada por una cuatricomía de colores cafés con tonalidad verde, con predominación de oro.

\section{Ficha de análisis iconográfico No. 6}
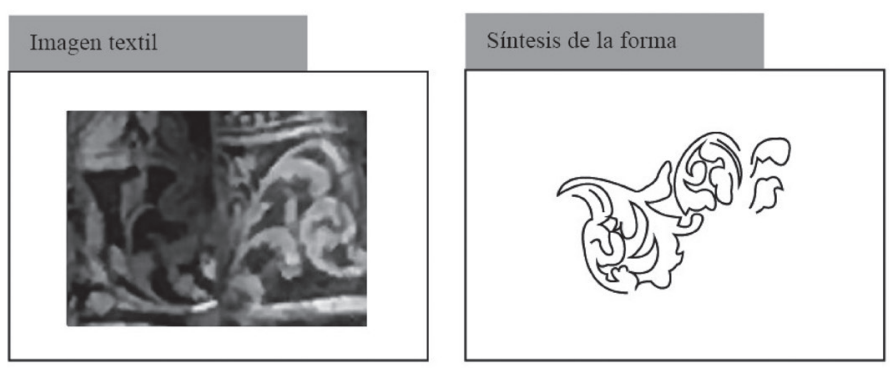

Referencia

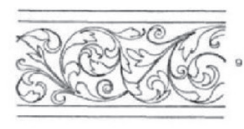

Imagen No 7. Cinta de Follaje y Zarcillos

Fuente: Meyer, 1929, Pag. 190

Figura 7. Ficha iconográfica 6. Fuente: elaboración propia 
En la Ficha de análisis icnonográfico Nro 7está representa la cenefa ubicada en la capa de la escultura, tiene una composición geométrica romboidal, la misma que se puede identificar a pesar de los pliegues que forma la capa, esta coincide con la imagen de cinta de follaje y zarcillos del manual de ornamentación (Meyer, 19219, p 188), además conserva imágenes orgánicas en su interior que se sitúan en el borde inferior de la capa. El color predominante es el oro, y está acompañada de una gama de amarillos.

\section{Ficha de análisis iconográfico No. 7}
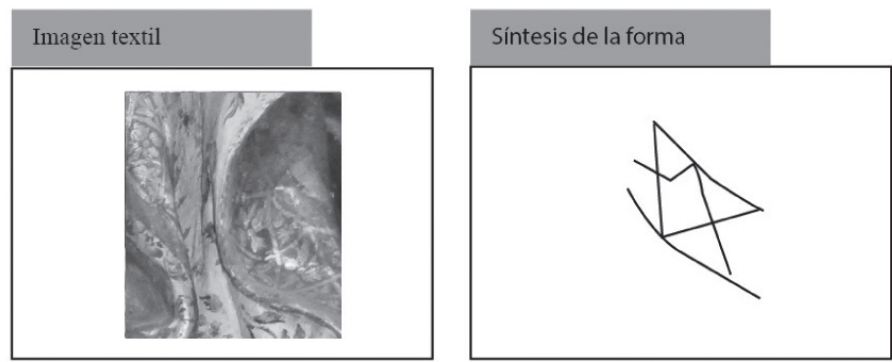

Paleta de color

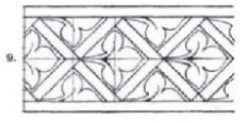

Imagen No 8. Cinta de Follaje y Zarcillos Fuente: Meyer, 1929, Pag. 188

Figura 8. Ficha iconográfica 7. Fuente: elaboración propia

Uno de las rasgos característicos de la imaginería quiteña es el recurso del pliegue, la ilusoria idea de continuo movimiento que se propone sobre la escultura, esconde dentro de sí fenómenos de color, de luminosidad de los dispositivos formales que evocan una idea ausente. Esta idea se transporta al repliegue del alma, a la libertad del artista para transmitir la codificación de un contexto que está lejano a simple vista del espectador. Esto obliga a interpretar aquello que no está presente, que no sólo remite a una idea concreta de la obra $y$, por otro lado, aquello que refiere a la imaginación pura.

El repliegue del barroco evoca aquellos conocimientos que se cruzan, contrastan, mestizan y emergen, convertidos en una morfología muy similar a la ya conocida. Es bien sabido que dentro del proceso de colonización, tanto ideológicamente como en la práctica, los conocimientos ancestrales se subordinan a la nueva cultura. Es en este mismo sentido que Deleuze y Vázquez (1989) se refieren a los pliegues del barroco, respecto de la transmutación de la materialidad, esta no se quiebra ni se rompe, antes bien se dobla, se repliega como las ondas de una túnica. De este modo los conocimientos ancestrales, altamente referenciados en las prácticas artesanales, se ocultan detrás de la materialidad y morfología delineada. "Un organismo se define por pliegues endógenos, mientras que la materia inorgánica tiene pliegues exógenos siempre determinados desde afuera o por el entorno". (Deleuze y Vázquez, 1989, p. 16). 
El contexto socio cultural de la época, influenciado por la iglesia decanta en las actividades de la población de Quito, ellas se propagan y trascienden evocando los enunciados impuestos; sin advertir que detrás de ellas se encierra el mensaje ancestral.

La producción de las artes y artesanías exhibe un desdoblamiento entre el autor y el ejecutante quien interpreta las obras de manera provisional. Lebinz, ante ello manifiesta que la esencia del arte, expresamente en el barroco, no cesa de hacer pliegues. Estos se conjugan en dos dimensiones el pliegue de la materia, cuyo factor fenomenológico evocará la materialidad de las obras; y el factor del alma, pliegue que le corresponde la libertad del alma y a sus predicados (Deleuze y Vázquez, 1989, p. 11).

Esta libertad se interpreta en la naturaleza de la materialidad que permite los repliegues de ella e interpreta los pliegues del alma, en el diseño de los textiles se puede evidenciar la tendencia a desbordar el espacio, que se conjuga con la necesidad de liberar la expresión. En la obra de San Lucas Evangelista, es posible identificar de forma inmediata los pliegues que emergen en la escultura, los que visten los imaginarios, la plasticidad con la cual se ornamentan las imágenes religiosas y se acentúa la apariencia. Asimismo también se puede apreciar cómo la iluminación del juego del claro-oscuro replica parte del espíritu de la época y tributa a disolver las fronteras del contenido y la forma.

Los aspectos materiales de la obra (color, materialidad, luminosidad, efectos, expresiones,) ofrecen un conjunto sistemático de información, un universo de elementos que, a pesar de ser limitados para el sentido de la interpretación puede ser bastante amplio.

La similitud de las formas orgánicas plasmadas en el textil, herencia de los grabados que se reprodujeron a lo largo de las colonias, con las especies nativas de la Real Audiencia de Quito dan cuenta de la fusión y transformación cultural, la cual se plasma en el diseño. Por lo tanto, el análisis morfológico permite identificar los signos textiles propios del contexto. El aporte de la mano de obra artesanal indígena y mestiza, en el diseño textil, se fusiona con elementos externos y a la vez constituyen un solo cuerpo que no ha sido analizado con detenimiento para entender cómo la cultura local se esconde y a su vez manifiesta en el repliegue de la indumentaria.

\section{Conclusiones}

En la medida que la producción textil artesanal de Quito paulatinamente decaía, la actividad artística había alcanzado su mayor auge. En efecto, la comercialización de las obras de los artistas quiteños llegaba a diferentes puntos de las colonias en América. En ese sentido, la transición del diseño artesanal textil, desde el tejido a la producción artística, es inescindible de los factores socio económicos. Además, el pliegue como parte fundamental de la filosofía del barroco, permitió ocultar los aspectos de transformación cultural materializados en el arte.

A pesar que la iconografía de la indumentaria sea heredada de España, el proceso artesanal de manufactura, los materiales incorporados, así como las formas que ornamentan la indumentaria, corresponden al aporte de los nativos y artesanos quiteños y mestizos, los cuales se plasman en el material, en la técnica y en la tipología. 
Los textiles artesanales son, entonces, portadores de los símbolos relativos al estatus, conllevan una carga mística que transfiere el espíritu del tejedor y del artesano al usuario. En ese sentido, y en tanto colonia y marcador de estatus determinadas clases sociales prefirieron los objetos que llegaban desde el exterior en detrimento de los producidos localmente. Este criterio se evidencia sobre todo en la etapa colonial, debido a las valoraciones coloniales propias de la época que privilegiaban la adquisición de los productos ibéricos y a las políticas económicas.

Finalmente, el diseño textil alimentado por formas orgánicas y de producción artesana locales, evidencian una transformación de la percepción del sentido estético de la población. Asimismo el aporte de los grupos étnicos y su producción artesanal a través del trabajo en los talleres artísticos, dan cuenta del engranaje social que permite construir un diseño textil propio y artesanal.

\section{Notas}

1. Las Reformas Borbónicas fueron una serie de ordenanzas de carácter económico, administrativo y militar, impulsadas por los Borbones en el siglo XVII y ejecutadas por Carlos III. Las reformas en lo referente a los textiles, incluyeron una alcabala (impuesto del $2 \%$ ) a las ropas de tierra, también se elevó el impuesto a los textiles importados, antes de las ordenanzas se pagaban 35 pesos por cada carga de ropas; después de estas, se incrementó en el 2.2 dos por ciento. Además, hacia 1770, se decretó el libre comercio, con lo cual perdieron aún más mercado los textiles de Quito. Borchart de Moreno, C., \& Moreno Yánez, S. (1995). Las Reformas Borbónicas en la Audiencia de Quito. Anuario Colombiano de Historia Social y de la Cultura, 0(22), 35-57. Recuperado de https://revistas.unal. edu.co/index.php/achsc/article/view/33761.

2. Una de las leyes que regularon el tráfico y comercio marítimo fue a la "Ley Cuarenta y Cinco. De la navegación, y comercio de las Islas Filipinas, China, Nueva España y Perú". (Ruiz, 2005, p.99), esta ordenanza velaba por el comercio ibérico, debido a los precios bajos de los productos y especies de Filipinas y China, podía ser una amenaza para la comercialización española. Esta ordenanza se confirma mediante en la Ley LXXVIII. La cual prohíbe el comercio, y el tráfico con el Perú, y Nueva España, en 1636.

3. La escasez de moneda en Quito, convirtió a los textiles en un medio de intercambio. Si bien la producción de los obrajes se había reducido, a nivel doméstico aún seguían operando y por lo tanto, generaban un ingreso para la ciudad. El trueque, como una forma de comercio, vincula pues el intercambio de mercancías a circunstancias sociales, tecnológicas e institucionales muy distintas. En consecuencia, el trueque puede verse como una forma especial de intercambio mercantil; una forma en la cual, por diversos motivos, el dinero no desempeña ningún papel o uno completamente indirecto (como mera unidad contable). (Appadurai, 1986) 


\section{Lista de Referencias bibliográficas}

Appadurai, A. (1991). La vida social de las cosas (p. 146). Perspectiva cultural de las mercancías.

Borchart de Moreno, C., y Moreno Yánez, S. (1995). Las Reformas Borbónicas en la Audiencia de Quito. Anuario Colombiano de Historia Social y de la Cultura, 0(22), 35-57. Recuperado de https://revistas.unal.edu.co/index.php/achsc/article/view/33761.

Bonialian, M. (2017). Comercio y atlantización del Pacífico mexicano y sudamericano: la crisis del lago indiano y del Galeón de Manila, 1750-1821. América Latina en la Historia Económica. Revista de Investigación, 24 (1), 7-36.

Bourdieu, P. (1979) La distinción. Criterio y bases sociales del gusto. Taurus: Buenos Aires. De Ulloa, A., \& Juan, J. (2002). Viaje a la América Meridional (Vol. 2). Dastin Export SL.

De Moreno, C y Yánez, S. (1995). Las reformas borbónicas en la Audiencia de Quito. Anuario Colombiano de Historia Social y de la Cultura, (22), 35-57.

Deleuze, G. (1989). El pliegue (Vol. 48). Grupo Planeta (GBS).

Durán, M. (2018). Los textiles indígenas en la época colonial. tributo, comercio e intercambio de mantas de algodón en los andes centrales neogranadinos, siglos XVI y XVII *. Historia y Sociedad, (35), 33-60. doi:http://dx.doi.org/10.15446/hys.n35.68452.

Espada J.y León, A. (2017). Arte textil barroco al servicio de las imágenes religiosas. Datatèxtil, (37).

Grández A, H. (2015) "Consumo de telas y grupos sociales en una comunidad monacal limeña: el Monasterio de Nuestra Señora del Prado."

Kennedy, A. (1993). La esquiva presencia indígena en el Arte Colonial Quiteño. Debates. Quito.

Kennedy, A. (2002). Arte y artistas quiteños de exportación. Arte de la Real Audiencia de Quito, siglos XVII-XIX,

Kennedy Troya, A. Criollización y Secularización de la Imagen Quiteña (S. XVII-XVIII). Universidad Estatal de Cuenca 185-203.

Martos, I. A. (1993). Aproximación a los textiles del siglo XVIII a través de la colección de pintura del Museo del Prado. Anthropos, 13.

Meyer, F. S. (1976). Manual de ornamentación. Gustavo Gili. Barcelona

Pantoja Barco, R. (2008). Afrodita barroca. Fragmentos para el estudio de una sensibilidad de la cultura. Popayán, siglos XVII y XVIII. Quito: Abya Yala

Rivera, N. M. (2013). Circulación de efectos de Castilla en el Virreinato de la Nueva Granada a finales del siglo XVIII. Fronteras de la historia: revista de historia colonial latinoamericana, 18(1), 211-249

Romero, X. (2000). Quito en los ojos de los viajeros: el siglo de la ilustración (No. 28). Editorial Abya Yala.

Ruiz Gutiérrez, A. (2005). El tráfico artístico entre España y Filipinas (1565-1815). Universidad de Granada, Servicio de Publicaciones de la Universidad de Granada.

Santos, B. D., y Fernando, A. (2011). Sánchez, C (1962). Los tejidos labrados de la España del siglo XVIII y las sedas imitadas del arte rococó en Minas Gerais (Brasil). Análisis formal y analogías. Riunet 
Tur, N. E. (1997). Producción y comercio de tejidos coloniales: los obrajes y chorrillos del Cusco, 1570-1820 (Vol. 23). Centro de Estudios Regionales Andinos, Bartolomé de Las Casas. Tyrer, R. B. (1976). The demographic and economic history of the Audiencia of Quito: Indian population and the textile industry, 1600-1800. University of California, Berkeley.

Abstract: This article aims to make an approach to textiles: its design and interpretation,
through the sculpture San Lucas Arcángel, restored in the workshop of Bernardo de Le-
garda, made in Quito in the second half of the eighteenth century, which express the handi-
craft process and incorporation of local elements in the textile design through it clothing.
The study highlights the materialization of cultural miscegenation, the result of the diverse
handicraft techniques and the relationships between the social strata of Quito society in the
colonial period. The design textile of this work demonstrates the process of miscegenation
that transcends the ethnic and social boundaries of the eighteenth century. The contribu-
tion of this research is intended to contribute to historical memory of textiles and clothing,
which are part of the cultural heritage, and have not been preserved or protected by the
policies and rescue management of heritage assets by the local government. The declaration
of Quito, as a Cultural Heritage of Humanity, by UNESCO, has allowed to safeguard cul-
tural assets, however, neither clothing nor textiles have not been considered in this process.

Palabras clave: Textile design - Baroque - Imaginery - Cultural miscegenation; handicraft processes

Resumo: Este artigo tem como objetivo fazer uma abordagem aos têxteis: o seu design e interpretação, através da escultura San Lucas Arcángel, restaurada na oficina de Bernardo de Legarda, feita em Quito na segunda metade do século XVIII, a mesma que dá conta a incorporação de elementos locais no design têxtil de suas roupas.

O estudo destaca os processos artesanais, a materialização da miscigenação cultural, resultado das diversas relações entre os estratos sociais da sociedade quito no período colonial. $\mathrm{O}$ design têxtil deste trabalho, demonstra o processo artesanais, de miscigenação que transcende as fronteiras étnicas e sociais do século XVIII. O contributo desta investigação pretende contribuir para a memória histórica dos têxteis e do vestuário, que fazem parte do património cultural, que não foram preservados ou protegidos pelas políticas e gestão de resgate de bens patrimoniais, por parte de do governo local. A declaração de Quito, como Patrimônio Cultural da Humanidade, pela UNESCO, permitiu salvaguardar os bens culturais, no entanto, vestuário e têxteis não foram considerados neste processo.

Palavras chave: Design têxtil - barroco - imaginário - miscigenação cultural - processos artesanais

[Las traducciones de los abstracts fueron supervisadas por el autor de cada artículo] 